\title{
Emblica Officinalis Leaves Extract as Corrosion Inhibitor
}

\author{
RENITA D'SOUZA and AMIT CHATTREE
}

Department of Chemistry, Sam Higginbottom Institute of Agriculture, Technology \& Sciences (Deemed-to-be-University), Allahabad-211007, U.P, India

renitavinaya@yahoo.com

Received 29 May 2015 / Accepted 26 June 2015

\begin{abstract}
Absract: The inhibition potentials of Emblica officinalis leaves extract (EOLE) was investigated by evaluating the corrosion behavior of mild steel immersed in $1 \mathrm{~N} \mathrm{HCl}$ solution containing varied concentration of the extract ranging from $200 \mathrm{ppm}$ to $1000 \mathrm{ppm}$. The corrosion inhibition of the extract was evaluated using weight loss studies. The inhibition efficiency increased with increase in concentration of the inhibitor and the highest \%IE was obtained at $1000 \mathrm{ppm}$. UV and SEM, provided the confirmatory evidence of improved surface condition, due to adsorption, for the corrosion protection.
\end{abstract}

Keywords: Adsorption, Corrosion, Emblica officinalis, Inhibition

\section{Introduction}

Numerous studies have been carried out on the corrosion of metals in different environment and their inhibition and most of the known inhibitors suitable for the corrosion inhibition of mild steel are heterocyclic compounds ${ }^{1-2}$. For these compounds their adsorption on the metal; surface is the initial step of inhibition ${ }^{3-5}$. The two main modes of adsorption that occur as a result of interaction between organic inhibitors and the metal surfaces are physical and chemical adsorption. The adsorption of inhibitor can be enhanced by the presence of hetero atoms such as $\mathrm{N}, \mathrm{O}, \mathrm{P}$ and $\mathrm{S}^{6-8}$. It has been reported that the extent of adsorption of an inhibitor is greatly influenced by the nature and surface coverage of the metal, mode of adsorption and the concentration of the inhibitor ${ }^{9-10}$.

Many industrial processes have put to use inorganic inhibitors for corrosion protection but as a result of cost and toxicity, attention is currently shifted towards the use of more ecofriendly inhibitors ${ }^{11}$. Natural products have been studied extensively as corrosion inhibitors both in product mixtures extracted from natural sources such as plants or essentially pure products derived from animals or plants (i.e. vitamins and amino acids). In the last years, Umoren et al. evaluated plant extracts as corrosion inhibitors, for example, Phyllanthus amarus $^{12}$, Pachylobus edulis ${ }^{13-14}$, Raphia hookeri ${ }^{15-16}$ and Ipomoea involcrata ${ }^{17}$ and also 
described the inhibitive action of ethanolic extracts from leaves of Chlomolaena Odorata L. (LECO) as eco-friendly corrosion inhibitor of acid corrosion of aluminum in $2 \mathrm{M} \mathrm{HCl}$, using hydrogen evolution and thermometric techniques ${ }^{18}$. Plant extracts have become important as environmentally acceptable, readily available and renewable source for wide range of inhibitors $^{19}$.

The present study was undertaken with the following objectives:

1. To determine the inhibition efficiency of Emblica officinalis leaves extract.

2. To investigate the formation of protective film on metal surface

\section{Experimental}

Green leaves of plant Emblica officinalis were washed and oven dried. $50 \mathrm{~g}$ of dried powder of leaves was boiled in $1000 \mathrm{~mL} 1 \mathrm{~N} \mathrm{HCl}$ with reflux condenser and kept overnight. Next day it was filtered and the filtrate volume was made upto $1000 \mathrm{~mL}$ using $1 \mathrm{~N} \mathrm{HCl} \mathrm{acid}{ }^{20}$.

\section{Specimen preparation}

Mild steel A (C=0.040\%, $\mathrm{Mn}=0.170 \%, \mathrm{~S}=0.170 \%, \mathrm{P}=0.006 \%, \mathrm{Si}=0.010 \%, \mathrm{Cr}=0.001 \%$, $\mathrm{Ni}=0.001 \%, \mathrm{~N}=0.005 \%, \mathrm{Al}=0.044 \%, \mathrm{Cu}=0.006$ and rest $\mathrm{Fe})$ and $\mathrm{B}(\mathrm{C}=0.162 \%$, $\mathrm{Mn}=0.900 \%, \mathrm{~S}=0.008 \%, \mathrm{P}=0.009 \%, \mathrm{Si}=0.008 \%, \mathrm{Al}=0.030 \%$ and rest $\mathrm{Fe}$ ) from $\mathrm{ESSAR}$ Steel Ltd., Hazira-394270, Dist, Surat, Gujarat, India having two different composition was utilized as test material for this work.

Coupons of rectangular specimens of the dimensions (1x5) $\mathrm{cm}^{2}$ were used. The samples were degreased with the vapours of trichloroethylene followed by mechanical polishing with different polishing papers (Coarse, Medium, Fine \& Extra fine). The samples were rinsed with ethanol, followed by distilled water and dried with a clean tissue paper ${ }^{21}$.

\section{Determination of inhibition efficiency by weight loss method}

The rectangular specimens with dimension of $(1 \times 5) \mathrm{cm}^{2}$ were weighed using digital weighing balance with $0.001 \mathrm{mg}$ accuracy and recorded as $\mathrm{W}_{\mathrm{i}}$. Then $25 \mathrm{~mL}$ of corrosive medium was introduced into reaction beakers. The pre-weighed coupons were fully immersed into each of the test media using twine tied to a small stick for support for $3 \mathrm{~h}$. The experimental set up was kept in a cool place at $295 \pm 1 \mathrm{~K}$ in the laboratory away from direct sunlight. Each coupon was retrieved from the test medium, washed under running water and then air dried. The coupons were reweighed and the final weights, $\mathrm{W}_{\mathrm{f}}$ was recorded. Weight loss of mild steel coupons immersed in $25 \mathrm{~mL}$ of the electrolyte with and without the extract of plant was determined ${ }^{22}$.

The percentage inhibition efficiency (IE\%) was then calculated from the following equation:

$$
\mathrm{I} E \%=\frac{\mathrm{W}_{0}-\mathrm{W}_{\text {inh }}}{\mathrm{W}_{0}} \times 100
$$

Where $\mathrm{W}_{\mathrm{o}}$ and $\mathrm{W}_{\text {inh }}$ are weight losses of mild steel in absence and presence of the extract $^{23}$.

\section{Investigating the formation of protective film on the surface of mild steel}

\section{Scanning electron microscopic (SEM) studies}

The change in surface morphology of modified mild steel was assessed using scanning Electron Microscopic technique ${ }^{21}$ and SEM photo images for magnification x1000 were recorded ${ }^{24}$, using Electron probe micro analyzer. 


\section{UV-Visible spectrophotometric studies}

The adsorption behavior of the organic molecules present in the plant extract was analysed using UV-Visible spectrum. The mild steel specimen A and B were immersed in a beaker having extract for 4 hours. After immersion they were dip washed 3-4 times in distilled water. Again specimens were dipped in $1 \mathrm{~N} \mathrm{HCl}$ for half an hour. This $\mathrm{HCl}$ acid solution was examined for UV-Visible spectrum using UV-Vis single beam Spectrophotometer ${ }^{25}$.

\section{Results and Discussion}

\section{Determination of inhibition efficiency by weight loss measurements}

Table 1 presents the weight loss for the mild steel samples (A) and (B) immersed in $1 \mathrm{~N} \mathrm{HCl}$ in absence and presence of varied concentrations of the Emblica officinalis leaves extract.

Table 1. Weight loss of mild steel (A) and (B) in $1 \mathrm{~N} \mathrm{HCl}$ in absence and presence of various concentrations of EOL extract $295 \pm 1 \mathrm{~K}$ for $3 \mathrm{~h}$

\begin{tabular}{ccccccc}
\hline Inhibitor & $\begin{array}{c}\text { Mild } \\
\text { steel }\end{array}$ & $\begin{array}{c}\text { Concentration } \\
\text { of inhibitor, } \\
\text { ppm }\end{array}$ & $\begin{array}{c}\text { Initial weight } \\
\text { of the coupon, } \\
\text { g }\end{array}$ & $\begin{array}{c}\text { Final weight } \\
\text { of the } \\
\text { coupon, g }\end{array}$ & $\begin{array}{c}\text { Difference } \\
\text { in weight, g }\end{array}$ & $\begin{array}{c}\% \\
\text { IE }\end{array}$ \\
\hline & & 0 (Blank) & 14.4098 & 14.3833 & 0.0265 & \\
& & 200 & 14.4417 & 14.4319 & 0.0098 & 63.0 \\
& & 400 & 14.4363 & 14.4276 & 0.0087 & 67.1 \\
& $\mathrm{~A}$ & 600 & 14.3106 & 14.3028 & 0.0078 & 70.5 \\
& & 800 & 14.2113 & 14.2657 & 0.0056 & 78.8 \\
& & 1000 & 14.2729 & 14.2680 & 0.0049 & 81.5 \\
& & $0($ Blank) & 23.5527 & 23.5271 & 0.0256 & \\
& & 200 & 23.4472 & 23.4390 & 0.0082 & 67.9 \\
& & 400 & 23.5702 & 23.5632 & 0.0070 & 72.6 \\
& & 600 & 23.5171 & 23.5125 & 0.0046 & 82.0 \\
& & 800 & 23.6845 & 23.6810 & 0.0035 & 86.3 \\
& 1000 & 23.4382 & 23.4353 & 0.0029 & 88.6 \\
\hline
\end{tabular}

It is observed that there is a significant reduction in the weight loss of the steel samples with the addition of the Emblica officinalis leaves extract in comparison with the sample in which no EOL extract was added and the highest inhibition efficiency was found at $1000 \mathrm{ppm}$ inhibitor $^{11}$.

\section{Scanning electron microscopy}

SEM micrograms of polished surface of mild steel A and B exposed for $4 \mathrm{~h}$ in $1 \mathrm{~N} \mathrm{HCl}$ solutions in absence and presence of 1000 ppm of EOLE are shown in Figure 1(a) \& (b). In comparison of SEM micrograms in absence and presence of the extract, there was a rough surface on mild steel in absence of the extract. There was a smooth surface with deposited extract on it in presence of the extract. In Figure 1(b), there were some scratches imprint which may be attributed to mechanical polishing by SiC course polishing paper $^{26}$.

\section{UV-Visible spectrophotometric studies}

Corrosion inhibition of mild steel in hydrochloric acid solution by EOLE can be explained on the basis of molecular adsorption. When inhibitor was introduced, acid soluble organic components dissolved in the solution interacted with the negatively charged mild steel surface. 
It caused adsorption of inhibitor molecules at metal/solution interface as supported by UV-Visible spectroscopy (Figure 2 \& 3). On the basis of this fact, it can be concluded that the organic compounds present in the EOLE were adsorbed on the mild steel surface ${ }^{25}$.
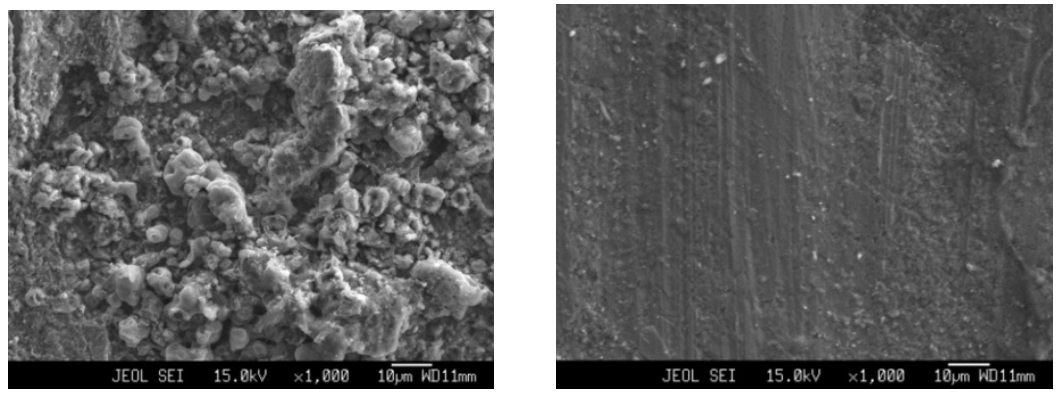

Figure 1(a). Scanning electron microgram of polished mild steel A (x1000) after exposed to (a) $1 \mathrm{~N} \mathrm{HCl}$ (b) $1 \mathrm{~N} \mathrm{HCl}$ containing $1000 \mathrm{ppm}$ of EOL extract
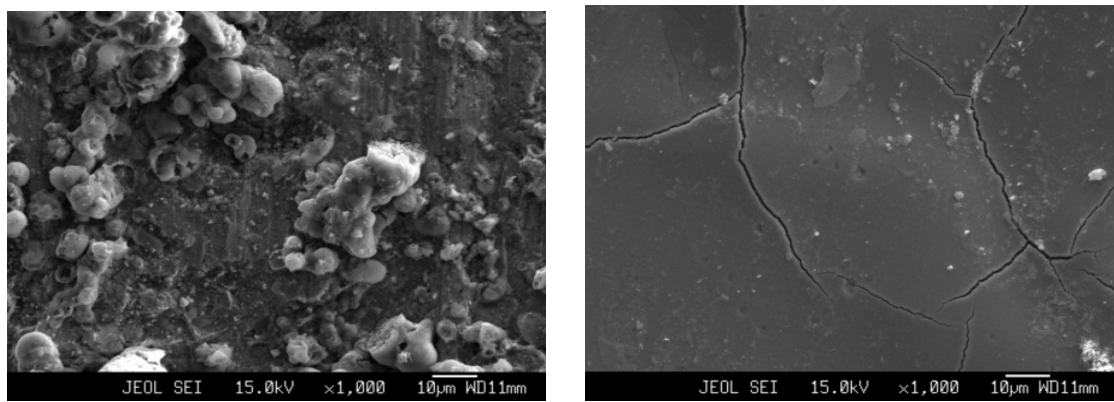

Figure 1(b). Scanning electron microgram (SEM) of polished mild steel B (x1000) after exposed to (a) $1 \mathrm{~N} \mathrm{HCl}$ (b) $1 \mathrm{~N} \mathrm{HCl}$ containing $1000 \mathrm{ppm}$ of EOL extract

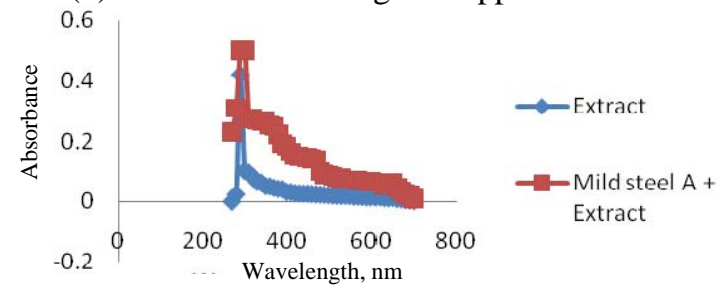

Figure 2 . UV-Visible spectra of the Emblica officinalis leaves extract and the washings of the mild steel A specimen incubated in extract

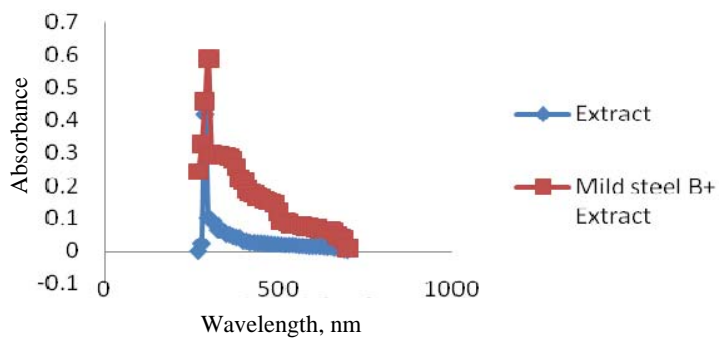

Figure 3. UV-Visible spectra of the Emblica officinalis leaves extract and the washings of the mild steel B specimen incubated in extract 


\section{Conclusion}

The Emblica officinalis leaves extract has good inhibition efficiency for preventing the corrosion of mild steel in $1 \mathrm{~N}$ hydrochloric acidic medium. EOL extract formed a protective layer on the surface of the mild steel and improved surface condition, due to adsorption, for the corrosion protection.

\section{Acknowledgements}

With profound sense of gratitude I place on record my sincere thanks to all those who have directly or indirectly helped me in the completion of this project work. I am grateful to the staff, teaching and non teaching for their noble guidance, innovative ideas and valuable suggestions. I thank my family and friends for their constant help and encouragement.

\section{References}

1. Ebenso E E, Okafor P C, Ekep U J, Ibok U J and Onuchukwu A I, J Che Soc Nig., 2004, 29(2), 15-25.

2. $\quad$ Acharya S and Opadhyay S N, Trans Indian Inst Met., 2004, 57(3), 297-306.

3. Bilgic L and Caliskan N, J Appl Electrochem., 2001, 31, 79-83; DOI:10.1023/A:1004182329826

4. El Ashry H E, Khamis E and Ibrahim A K, British corrosion, J., 2004, 35, 150-164.

5. Quan Z, Chen S, Li Y and Cui X, Corros Sci., 2002, 44, 703-715; DOI:10.1016/S0010-938X(01)00077-4

6. Umoren S A, Ebenso E E, Okafor P C and Ekpe U J, Pigment Resin Technol., 2006, 35(5), 284-292; DOI:10.1108/03699420610692896

7. Ebenso E E, Bull Electrochem., 2004, 12, 551-559.

8. Ehteshanmzade M, Shahradi T and Hosseini M G, Appl Surf Sci., 2005, 252(8), 29492959; DOI:10.1016/j.apsusc.2005.05.003

9. Ashssi-Sorkabi H and Ghalesaolz-Jeddi N, Mat Chem Phys., 2005, 92(2-3), 480-486; DOI:10.1016/j.matchemphys.2005.01.059

10. Minhaj, Saini P A, Quraishi M A and Farooqi I H, Corrosion Prevention Control, U K., 1999, 46(2), 32-38.

11. Alaneme K K and Olusegun S J, Leonardo J Sci., 2012, 11(20), 59-70.

12. Okafor P C, Ikpi M E, Uwah I E, Ebenso E E, Ekpe U J and Umoren S A, Corrs Sci., 2008, 50(8), 2310-2317; DOI:10.1016/j.corsci.2008.05.009

13. Umoren S A, Obot I B and Ebenso E F, J Chem., 2008, 5(2), 355-364; DOI:10.1155/2008/138407

14. Umoren S A and Ekanema U F, Chem Engg Comm., 2010, 197(10), 1339-1356; DOI:10.1080/00986441003626086

15. Umoren S A and Ebenso E E, Pigment Resin Tech., 2008, 37(3), 173-182; DOI:10.1108/03699420810871020

16. Umoren S A, Obot I B, Obenso E E and Obi-Egbedi N O, Desalination, 2009, 247(1), 561-572; DOI:10.1016/j.desal.2008.09.005

17. Obot I B, Obi-Egbedi N O, Umoren S A and Ebenso E E, Inter J Electrochem Sci., 2010, 5(7), 994-1007.

18. Obot I B and Obi-Egbedi N O, J Appl Elctrochem., 2010, 40(11), 977-1984; DOI:10.1007/s10800-010-0175-X

19. Raja P B and Sethuraman M G, Mater Lett., 2008, 62(1), 113-116; DOI:10.1016/j.matlet.2007.04.079 
20. Saratha R and Vasudha V G, J Chem., 2009, 7(3), 677-684;

DOI:10.1155/2010/162375

21. Rajappa S K and Venkatesh T V, J Appl Chem., 2015, 4(1), 212-220.

22. Osuwa J C and Okere C, J Environ Sci Toxicol Food Technol (IOSR-JESTFT), 2013, 4(5), 61-65.

23. Ramananda M S, J Mater Environ Sci., 2013, 4(1), 117-126.

24. Rethinnagiri V, Jeyaprakash P, Arunkumar M, Maheswaran V and Madhiyalagan A, Adv Appl Sci Res., 2012, 3(3), 1718-1726.

25. Gopal Ji, Shukla S K, Dwivedi P, Sundaram S, Ebenso E E and Prakash R, Inter J Electrochem Sci., 2012, 7, 12146-12158;

26. Mohamad A B, Kadhum A A H, Al-Amiery A A, Ying L C and Musa A Y, Metals Mat Int., 2014, 20(3), 459-467; DOI:10.1007/s12540-014-3008-3 